http://jmscr.igmpublication.org/home/ ISSN (e)-2347-176x ISSN (p) 2455-0450 crossref DOI: https://dx.doi.org/10.18535/jmscr/v7i8.74

\title{
Effectiveness of Hydroxyurea Therapy in Sickle Cell Disease and Sickle Cell Trait
}

\author{
Authors \\ Dr Darshana S Thakur ${ }^{1}$, Dr Mrinalini Hardas², Dr Prashant.P. Joshi ${ }^{3}$, \\ Dr M.S.Pandharipande ${ }^{4}$ \\ ${ }^{1}$ Ex-resident, ${ }^{2}$ Assistant Professor, ${ }^{3}$ Professor and Head, ${ }^{4}$ Associate Professor \\ Dept.of. Medicine IGGMC, Nagpur, India \\ Corresponding Author \\ Dr Mrinalini Hardas
}

\begin{abstract}
Background and Objectives: Vaso-occlusive crisis, a common clinical presentation of sickle cell disease is a major cause of morbidity. It has been observed in some cases of sickle cell trait also. Hydroxyurea exerts beneficial effect primarily by increasing fetal hemoglobin and also through other mechanisms. The Arabian-Indian haplotype of Hemoglobin $S$ is associated with moderate form of disease and high fetal hemoglobin level. This study was conducted to assess the clinical and hematological response of homozygous and heterozygous cases of Hemoglobin $S$ to hydroxyurea therapy. The adverse reactions to the drug were also observed.

Material and Methods: The study, an interventional case series, was conducted at a teaching hospital in Central India during January 2013 to December 2014.A total of 54 cases satisfying eligibility criteria were recruited. 9 cases ( 2 due to severe reaction and 7 due to poor compliance) were excluded. Thus study comprised of 45 cases of sickle cell disease (36 homozygous and 9 heterozygous). Detailed clinical examination, baseline investigations and HPLC were performed. Cases received $10 \mathrm{mg} / \mathrm{kg} /$ day of Hydroxyurea and were followed up weekly in sickle-cell opd for compliance, effectiveness and adverse reactions. At the end of one year of hydroxyurea therapy, baseline investigations and HPLC were repeated. Appropriate statistical analysis was done using STATA version 13.1.

Results: Statistically significant clinical response, namely decrease in the frequency of vaso-occlusive crises and duration of hospitalization and improvement of clinical score was observed ( $p<0.0001)$ in homozygous and heterozygous cases of sickle cell disease. Statistically significant hematological response $(p<0.0001)$ namely, increase in hemoglobin, mean corpuscular volume of red cell and fetal hemoglobin level, decrease in total leukocyte count was observed in homozygous and heterozygous cases of sickle cell disease. Hydroxyurea was well tolerated.

Conclusion: Hydroxyurea is effective in homozygous cases of sickle cell disease. Hydroxyurea is effective in HPLC proven heterozygous cases of sickle cell; however, detailed hemoglobin structure and genetic studies recruiting larger number of these cases is recommended. Hydroxyurea is effective despite high level of fetal hemoglobin. Hydroxyurea is well tolerated and must be administered with regular monitoring.

Keywords: Sickle cell disease (SS), sickle cell trait (AS), hydroxyurea, fetal hemoglobin, clinical response, hematological response, adverse reactions.
\end{abstract}

\section{Introduction}

Sickle cell anemia, a heritable hematologic disease, has various clinical presentations; anemia, vaso-occlusive crisis, aplastic crisis, crippling avascular bone necrosis and osteomyelitis to name a few. It can manifest in infancy or may remain asymptomatic till adulthood. Clinical presentation varies according to region and patients. This 
phenotypic heterogenicity despite mutational unicity led to the identification of five haplotypes of beta-globin gene-Benin, Senegal, Bantu, Cameroon and Arabian-Indian. Arabian Indian haplotype, prevalent in India, is associated with moderate form of disease. ${ }^{1}$

Our hospital is a tertiary care centre which caters to Sickle Cell patients throughout the year. Severe vaso-occlusive crisis similar to homozygous state have been consistently observed over the years in some cases of sickle cell trait also; however, there is limited published literature.$^{2}$ Higher level of Fetal hemoglobin $(\mathrm{Hb} \mathrm{F})$ is associated with reduction in the frequency and severity of vasoocclusive crisis. $^{3}$ Hydroxyurea, a myelo suppressive agent increases the $\mathrm{HbF}$ level. Usefulness of hydroxyurea in sickle cell disease has been demonstrated in Multicentre Study of Hydroxyurea (MSH) ${ }^{4}$. Hydroxyurea has been found to be effective in heterozygous conditions like hemoglobin SD- Punjab and hemoglobin $\mathrm{SC}^{5,6}$. Arabian-Indian haplotype is associated with higher HbF level. ${ }^{7}$ Hence it may be argued that hydroxyurea may not be beneficial; however hemorheologic actions of hydroxyurea also contribute to its role in management of vasoocclusive crises. Therefore we have attempted to evaluate the effectiveness of hydroxyurea in homozygous and heterozygous sickle cell patients in vaso-occlusive crisis and correlate the response with baseline fetal hemoglobin level.

\section{Aims and Objectives}

1. To assess the clinical response to hydroxyurea therapy by comparing the frequency of vaso-occlusive crisis during the preceding year, with frequency during one year, of hydroxyurea therapy in sickle cell patients.

2. To assess the hematological response to hydroxyurea therapy by comparing fetal hemoglobin and Hemogram at baseline and at the end of one year of hydroxyurea therapy in sickle cell patients.
3. To compare the clinical \{i.e. frequency of acute crisis\} and hematological \{i.e. $\mathrm{HbF}$ levels and Hemogram $\}$ response to hydroxyurea drug therapy between sickle cell disease and sickle cell trait patients.

4. To study Adverse Drug Reactions to the hydroxyurea therapy.

\section{Material and Methods}

This Interventional, non-randomized prospective case series was conducted with the permission of The Institutional Ethics committee. The cases of sickle cell disease (SS) and trait (AS), fulfilling all eligibility criteria, attending general medicine, sickle cell OPD and medicine wards were included after obtaining written informed consent. Sickle cell disease (SS) and sickle cell trait (AS) patients, age > 12 yrs with >3 painful vasoocclusive crises per year were included. Following cases were excluded-a) Patients with pancytopenia Platelet count less than 100,000/cu.mm, Neutrophil count less than 2,500/cu.mm and Haemoglobin less than $6 \mathrm{~g} / \mathrm{dl}$ (in accordance with $\mathrm{MSH})^{4}$ b) Patients who have received blood transfusion within 3 months at recruitment or who will receive blood transfusion in last 3 months of intervention to eliminate erroneous estimation of $\mathrm{HbF}$ levels c)Noncompliant cases d)pregnant women e) cases who develop adverse reactions to the drug.

\section{Definitions}

1. Vaso-occlusive crisis (VOC): A painful crisis was defined as a visit to a medical facility that lasted more than four hours, for acute sicklingrelated pain, which was treated with a parenterally administered narcotic. The episode of pain in the extremities, back, abdomen, chest or head that lasted for some hours could not be explained except by sickle cell state. ${ }^{4}$ Only those crises which led to medical visit and admission to emergency department or indoor wards were included. The painful crises managed at home with hydration and oral analgesics were excluded. All our cases had 
the documentary evidence of having received parenteral tramadol.

2. Compliance with the drug hydroxyurea: compliance was checked by pill count. Patients with more than $90 \%$ compliance with the drug were included.

After recruiting sickle cell patients (both SS and AS pattern) as per above eligibility criteria a detailed history and complete clinical examination was performed. Clinical score was calculated (.see table) Complete blood count was done and diagnosis of sickle cell disease and trait was confirmed by High Performance Liquid Chromatography (HPLC) method. ${ }^{8}$ Then patients were started on hydroxyurea drug $10 \mathrm{mg} / \mathrm{kg} / \mathrm{day} .{ }^{4}$ Patients were regularly followed up every week in the sickle cell clinic for one year; regular complete blood count monitoring and pill count was done. HPLC and complete blood count were done again at the end of one year.

Statistical analysis: continuous variables (age, hemoglobin, fetal hemoglobin, mean corpuscular volume, platelet count, total leukocyte count) are presented as Mean \pm SD. Median and Range were calculated for non-normalized data. Categorical variables (sex, pattern, vaso-occlusive crisis, hospitalizations due to severe vaso-occlusive crisis, blood transfusions and clinical score) are expressed as actual numbers and percentages. Continuous variables were compared at baseline and after one year of hydroxyurea therapy by performing paired $-t$ test for normalized data and Wilcoxon Sign-rank test was applied for non normalized data. Change in hemoglobin during hydroxyurea therapy was assessed by ANOVA test.

The correlation of clinical and hematological parameters with baseline fetal hemoglobin levels was assessed by calculating Pearsons correlation coefficient.

The p-value $<0.05$ was considered as statistically significant. Statistical software STATA version 13.1 was used for statistical analysis.

Scoring system for clinical evaluation of patients ${ }^{9}$

\begin{tabular}{|l|c|c|c|c|c|}
\hline SCORE $\rightarrow$ & $\mathbf{1}$ & $\mathbf{2}$ & $\mathbf{3}$ & $\mathbf{4}$ & $\mathbf{5}$ \\
\hline Vaso-occlusive crisis in preceding year & 0 to 1 & $>1-3$ & $>3-5$ & $>5-8$ & $>8-12$ \\
\hline $\begin{array}{l}\text { Hospitalizations due to vaso-occlusive } \\
\text { crises in last 1 year }\end{array}$ & 0 & $1-2$ & $3-4$ & $\geq 5$ & \\
\hline Blood transfusions in last 1 year & 0 & $1-2$ & $3-4$ & $\geq 5$ & \\
\hline Acute chest syndrome & No & Yes & & & \\
\hline Stroke & No & Yes & & & \\
\hline Avascular necrosis of femur & No & Yes & & & \\
\hline Spleen size & $\begin{array}{l}\text { Not/just } \\
\text { palpable }\end{array}$ & $3-4 \mathrm{~cm}$ & $5-7 \mathrm{~cm}$ & & \\
\hline
\end{tabular}

\section{Observations and Results}

Table 1. Clinical parameters before and after starting hydroxyurea

\begin{tabular}{|c|c|c|c|}
\hline CLINICAL PARAMETERS & $\begin{array}{c}\text { one year before starting } \\
\text { hydroxyurea }(\mathbf{N}=45) \\
\text { Mean }( \pm \text { SD) } \\
\text { (Range) }\end{array}$ & $\begin{array}{c}\text { During one year of } \\
\text { therapy }(\mathbf{N}=45) \\
\text { Mean }( \pm \mathrm{SD}) \\
\text { (Range) }\end{array}$ & p-value \\
\hline Frequency of VOC & $\begin{array}{l}10.47( \pm 6.59) \\
3-25\end{array}$ & $\begin{array}{l}1.93( \pm 3.09) \\
0-12\end{array}$ & $<0.0001$ \\
\hline $\begin{array}{l}\text { Patients requiring hospitalization } \\
\text { due to VOCs }\end{array}$ & 38 & 15 & $<0.0001$ \\
\hline Duration of hospitalization (days) & $6.06( \pm 2.41)$ & $3.76( \pm 1.37)$ & 0.0011 \\
\hline $\begin{array}{l}\text { Frequency of hospitalizations due } \\
\text { to VOCs }\end{array}$ & $\begin{array}{c}2.04( \pm 1.30) \\
0-6\end{array}$ & $\begin{array}{c}0.44( \pm 0.72) \\
0-3\end{array}$ & $<0.0001$ \\
\hline number of blood transfusions & $\begin{array}{c}0.31( \pm 0.73) \\
0-4\end{array}$ & $\begin{array}{c}0.02( \pm 0.15) \\
0-1\end{array}$ & 2.725 \\
\hline clinical score & $\begin{array}{c}11.75( \pm 1.71) \\
9-17\end{array}$ & $\begin{array}{c}8.29( \pm 1.73) \\
6-14\end{array}$ & $<0.0001$ \\
\hline
\end{tabular}


Table 2 Hematological parameters before and after starting hydroxyurea

\begin{tabular}{|c|c|c|c|}
\hline $\begin{array}{l}\text { HEMATOLOGICAL } \\
\text { PARAMETERS }\end{array}$ & 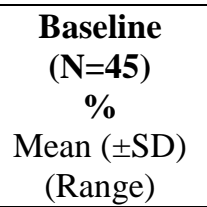 & $\begin{array}{c}\text { After one year of } \\
\text { therapy }(\mathbf{N}=45) \\
\% \\
\text { Mean }( \pm S D) \\
\text { (Range) }\end{array}$ & p-value \\
\hline Fetal Hemoglobin(\%) & $\begin{array}{c}15.52( \pm 9.14) \\
0.4-34.1\end{array}$ & $\begin{array}{c}19.73( \pm 11.02) \\
0.7-44.6 \\
\end{array}$ & $<0.0001$ \\
\hline Hemoglobin(g/dl) & $\begin{array}{c}8.58( \pm 1.38) \\
6-12.2 \\
\end{array}$ & $\begin{array}{c}10.30( \pm 1.45) \\
7.3-15 \\
\end{array}$ & $<0.0001$ \\
\hline $\begin{array}{ll}\text { Mean } & \text { Corpuscular } \\
\text { Volume(fl) } & \\
\end{array}$ & $\begin{array}{c}77.36( \pm 9.50) \\
60-96\end{array}$ & $\begin{array}{c}90.45( \pm 7.67) \\
67.8-113 \\
\end{array}$ & $<0.0001$ \\
\hline Total Leukocyte Count $(/ \mu \mathrm{L})$ & $\begin{array}{c}9795.55 \\
( \pm 4491.14) \\
4200-5000\end{array}$ & $\begin{array}{c}6373.33 \\
( \pm 2498.67) \\
4000-18000\end{array}$ & $<0.001$ \\
\hline $\begin{array}{l}\text { Platelet count } \\
(\text { lac } / \mu \mathrm{L})\end{array}$ & $\begin{array}{l}2.34( \pm 1.16) \\
1-5.16\end{array}$ & $\begin{array}{c}2.21( \pm 0.96) \\
1-5\end{array}$ & 0.0609 \\
\hline
\end{tabular}

Table 3 Clinical response to hydroxyurea drug therapy in homozygous (SS) cases

\begin{tabular}{|l|c|c|c|c|}
\hline Clinical parameters & $\begin{array}{c}\text { one year before } \\
\text { starting } \\
\text { hydroxyurea } \\
(\mathbf{N}=\mathbf{3 6}) \text { Mean( } \pm \text { SD })\end{array}$ & $\begin{array}{c}\text { During one year } \\
\text { oftherapy }(\mathbf{N = 3 6}) \\
\text { Mean }( \pm \text { SD) }\end{array}$ & $\begin{array}{c}\text { Mean change } \\
{[\% \text { mean change] }}\end{array}$ & p-value \\
\hline $\begin{array}{l}\text { frequency of vaso- } \\
\text { occlusive crisis }\end{array}$ & $11.02( \pm 6.76)$ & $2.16( \pm 3.36)$ & $\begin{array}{c}8.66( \pm 6.77) \\
{[78.58 \%]}\end{array}$ & 0.0001 \\
\hline $\begin{array}{l}\text { frequency } \\
\text { hospitalizations }\end{array}$ & $2.11( \pm 1.32)$ & $0.44( \pm 0.73)$ & $\begin{array}{c}1.66( \pm 1.35) \\
{[78.67 \%]}\end{array}$ & $<0.0001$ \\
\hline $\begin{array}{l}\text { number of blood } \\
\text { transfusions }\end{array}$ & $0.33( \pm 0.79)$ & $0.02( \pm 0.16)$ & $\begin{array}{c}0.30( \pm 0.82) \\
{[90.90 \%]}\end{array}$ & 0.0322 \\
\hline clinical score & $11.86( \pm 1.77)$ & $8.41( \pm 1.75)$ & $3.44( \pm 2.18)$ & $<0.0001$ \\
& & & & \\
\hline
\end{tabular}

Table 4 Hematological response to hydroxyurea drug therapy in homozygous (SS) cases

\begin{tabular}{|l|c|c|c|c|}
\hline $\begin{array}{l}\text { Hematological } \\
\text { parameters }\end{array}$ & $\begin{array}{c}\text { Baseline }(\mathbf{N}=\mathbf{3 6}) \\
\text { Mean } \pm \text { SD }\end{array}$ & $\begin{array}{c}\text { After one year of } \\
\text { therapy }(\mathbf{N}=36) \\
\text { Mean } \pm \text { SD }\end{array}$ & $\begin{array}{c}\text { mean change } \\
{[\% \text { mean change] }}\end{array}$ & p-value \\
\hline $\begin{array}{l}\text { fetal } \\
\text { hemoglobin }(\%)\end{array}$ & $19.07( \pm 6.27)$ & $24.25( \pm 6.83)$ & $\begin{array}{c}5.18( \pm 4.64) \\
{[27.16 \%]}\end{array}$ & $<0.0001$ \\
\hline $\begin{array}{l}\text { Hemoglobin } \\
(\mathrm{gm} / \mathrm{dL})\end{array}$ & $8.38( \pm 1.16)$ & $10.21( \pm 1.53)$ & $\begin{array}{c}1.83( \pm 1.34) \\
{[21.83 \%]}\end{array}$ & $<0.0001$ \\
\hline $\begin{array}{l}\text { Mean corpuscular } \\
\text { volume(fL) }\end{array}$ & $78.31( \pm 9.06)$ & $90.56( \pm 7.87)$ & $\begin{array}{c}12.259( \pm 9.94) \\
{[15.65 \%]}\end{array}$ & $<0.001$ \\
\hline $\begin{array}{l}\text { Total leukocyte } \\
\text { count }(/ \mu \mathrm{L})\end{array}$ & 10217.78 \\
\hline $\begin{array}{l}\text { platelet } \\
\text { count }(\mathrm{lac} / \mu \mathrm{\mu})\end{array}$ & $4846.73)$ & $6655.55( \pm 3433.43)$ & $\begin{array}{c}3562.22( \pm 3433.43) \\
{[34.86 \%]}\end{array}$ & $<0.001$ \\
\hline
\end{tabular}

Table.5 Clinical response to hydroxyurea drug therapy in Sickle cell trait (AS) cases

\begin{tabular}{|l|c|c|c|c|}
\hline $\begin{array}{l}\text { Clinical } \\
\text { parameters }\end{array}$ & $\begin{array}{c}\text { one year before starting } \\
\text { hydroxyurea(N=9) } \\
\text { mean( }( \pm \mathbf{S D})\end{array}$ & $\begin{array}{c}\text { During one year } \\
\text { of therapy(N=9) } \\
\text { mean( }( \pm \mathbf{S D})\end{array}$ & mean change & p-value \\
\hline $\begin{array}{l}\text { frequency of vaso- } \\
\text { occlusive crisis }\end{array}$ & $8.22( \pm 5.65)$ & $1( \pm 1.22)$ & $7.22( \pm 5.86)$ & 0.0061 \\
\hline $\begin{array}{l}\text { frequency of } \\
\text { hospitalizations }\end{array}$ & $1.77( \pm 1.20)$ & $0.24( \pm 0.72)$ & $\begin{array}{c}1.33( \pm 3 \%] \\
{[75.14 \%]}\end{array}$ & 0.0114 \\
\hline $\begin{array}{l}\text { number of blood } \\
\text { transfusions }\end{array}$ & $0.22( \pm 0.44)$ & 0 & $0.22( \pm 0.44)$ & 0.1090 \\
\hline clinical score & $11.33( \pm 1.41)$ & $7.77( \pm 0.97)$ & $\begin{array}{c}3.55( \pm 100 \%] \\
{[31.33 \%]}\end{array}$ & $<0.0001$ \\
\hline
\end{tabular}


Table.6 Hematological response to hydroxyurea drug therapy in Sickle cell trait (AS) cases

\begin{tabular}{|c|c|c|c|c|}
\hline $\begin{array}{l}\text { Hematological } \\
\text { parameters }\end{array}$ & $\begin{array}{c}\text { Baseline }(\mathrm{N}=9) \\
\text { mean }( \pm \mathrm{SD})\end{array}$ & $\begin{array}{c}\text { After one year of } \\
\text { therapy } \\
(\mathrm{N}=9) \\
\text { mean }( \pm \mathrm{SD})\end{array}$ & mean change & p-value \\
\hline Fetal hemoglobin(\%) & $\begin{array}{c}1.31 \\
( \pm 1.77) \\
\end{array}$ & $\begin{array}{c}1.63 \\
( \pm 1.89) \\
\end{array}$ & $\begin{array}{c}0.32( \pm 0.25) \\
{[24.42 \%]}\end{array}$ & 0.0032 \\
\hline Hemoglobin $(\mathrm{gm} / \mathrm{dl})$ & $\begin{array}{c}9.35 \\
( \pm 1.92)\end{array}$ & $\begin{array}{c}10.62 \\
( \pm 1.13)\end{array}$ & $\begin{array}{c}1.26( \pm 1.34) \\
{[13.47 \%]}\end{array}$ & 0.0258 \\
\hline $\begin{array}{l}\text { Mean corpuscular } \\
\text { volume(fL) }\end{array}$ & $73.55( \pm 10.82)$ & $\begin{array}{c}90 \\
( \pm 7.21)\end{array}$ & $\begin{array}{c}16.44( \pm 5.46) \\
{[22.35 \%]}\end{array}$ & $<0.001$ \\
\hline $\begin{array}{l}\text { total leukocyte } \\
\operatorname{count}(/ \mu \mathrm{L})\end{array}$ & $\begin{array}{c}8106.66 \\
( \pm 2038.11)\end{array}$ & $\begin{array}{c}5244.44 \\
( \pm 1218.72)\end{array}$ & $\begin{array}{c}2866.22( \pm 1586.77) \\
{[35.35 \%]}\end{array}$ & 0.0006 \\
\hline $\begin{array}{ll}\begin{array}{l}\text { platelet } \\
(\text { lac } / \mu \mathrm{L})\end{array} & \text { count }\end{array}$ & $2.03( \pm 0.92)$ & $2.0( \pm 0.60)$ & $\begin{array}{c}0.03( \pm 0.40) \\
{[1.47 \%]}\end{array}$ & 0.4096 \\
\hline
\end{tabular}

Table.7 Comparison of clinical and hematological response to one year of hydroxyurea therapy between SS and AS cases

\begin{tabular}{|l|c|c|c|}
\hline variable & $\begin{array}{c}\text { SS }(\mathrm{n}=36) \\
\text { Mean change }( \pm \text { SD) }\end{array}$ & $\begin{array}{c}\text { AS }(\mathrm{n}=9) \\
\text { Mean change }( \pm \text { SD })\end{array}$ & -value \\
\hline Frequency of VOC & $8.66( \pm 6.77)$ & $7.22( \pm 5.86)$ & 0.6582 \\
\hline Hospitalizations & $1.66( \pm 1.35)$ & $1.33( \pm 0.72)$ & 0.5293 \\
\hline Blood transfusions & $0.30( \pm 0.82)$ & $0.22( \pm 0.44)$ & 0.5108 \\
\hline Clinical score & $3.44( \pm 2.18)$ & $3.55( \pm 1.50)$ & 0.8864 \\
\hline Fetal hemoglobin $(\%)$ & $5.18( \pm 4.64)$ & $0.32( \pm 0.25)$ & 0.0032 \\
\hline Hemoglobin $(\mathrm{gm} / \mathrm{dL})$ & $1.83( \pm 1.34)$ & $1.26( \pm 1.34)$ & 0.0910 \\
\hline MCV $(\mathrm{fL})$ & $12.25( \pm 9.94)$ & $16.44( \pm 5.46)$ & 0.2332 \\
\hline TLC $(/ \mu \mathrm{L})$ & $3562.22( \pm 3433.43)$ & $2866.22(1586.77)$ & 0.7874 \\
\hline
\end{tabular}

Table.8 Co-relation of response of Clinical and hematological parameters with baseline HbF level

\begin{tabular}{|c|c|c|c|}
\hline Sr. No. & Parameters & r-value & p-value \\
\hline a. & Change in $\mathrm{VOC}^{*}$ & 0.0254 & 0.8687 \\
\hline b. & Change in Hospitalizations & -0.1094 & 0.4742 \\
\hline c. & Change in $\mathrm{BT}^{* *}$ & -0.0939 & 0.5394 \\
\hline d. & Change in Clinical score & -0.1575 & 0.3013 \\
\hline e. & Change in $\mathrm{Hb}^{\odot}$ & 0.0392 & 0.7981 \\
\hline f. & Change in $\mathrm{MCV}^{\alpha}$ & -0.3042 & $0.0422, \mathrm{~S}$ \\
\hline g. & Change in $\mathrm{HbF}^{\Theta}$ & 0.1988 & 0.1905 \\
\hline h. & Change in Platelet count & -0.0427 & 0.7805 \\
\hline i. & Change in TLC $\mathrm{x}$ & -0.1307 & 0.3921 \\
\hline
\end{tabular}

*VOC $=$ vaso-occlusive crisis; $* * \mathrm{BT}=$ blood Transfusions; ${ }^{\circ} \mathrm{Hb}=$ hemoglobin, ${ }^{\circ} \mathrm{MCV}=$ mean corpuscular hemoglobin

, ${ }^{\Theta} \mathrm{HbF}=$ fetal hemoglobin, ${ }^{\mathrm{T}} \mathrm{TLC}=$ total leukocyte count

Table.9 Adverse drug reactions (all 54 patients were considered)

\begin{tabular}{|l|c|c|c|}
\hline $\begin{array}{l}\text { Sr. } \\
\text { No. }\end{array}$ & System & Side effect & $\begin{array}{c}\text { Cases (\%) } \\
(\mathbf{N}=\mathbf{5 4})\end{array}$ \\
\hline 1 & Hematology & Thrombocytopenia only & $5(9.25 \%)$ \\
\hline & & Leucopenia only & $3(5.55 \%)$ \\
\hline & & Thrombocytopenia+leucopenia & $2(3.7 \%)$ \\
\hline & & Pancytopenia & $1(1.8 \%)$ \\
\hline 2 & Gastro-intestinal tract & Abdominal pain & $2(3.70 \%)$ \\
\hline & & Nausea & $10(18.51 \%)$ \\
\hline 3 & Dermatology & Skin hyperpigmentation & $5(9.25 \%)$ \\
\hline & & Nail hyperpigmentation & $6(11.11 \%)$ \\
\hline & & Hair loss & $1(1.85 \%)$ \\
\hline & & Skin rash & $1(1.85 \%)$ \\
\hline 4. & Neurology & Vertigo & $2(3.7 \%)$ \\
\hline 5. & Others & Edema feet & $1(1.8 \%)$ \\
\hline & & Weight loss & $1(1.8 \%)$ \\
\hline
\end{tabular}




\section{Results}

We recruited 54 cases; 2 cases developed severe adverse drug reactions and hence hydroxyurea was discontinued in them. 7 cases were not compliant with the drug. Remaining 45 cases were more than $90 \%$ compliant with the drug.

The study therefore comprised of 45 cases-36 cases of sickle cell disease and 9 cases of sickle cell trait. Mean age of cases was 22.97 years(range 13-42 years). 16 males and 20 females were recruited in sickle cell disease(homozygous) cases while all 9 cases of sickle cell trait were females.

We observed that after starting hydroxyurea therapy, 23 out of 45 patients $(51.11 \%)$ patients did not have further crisis. The mean frequency of vaso-occlusive crisis decreased by $81.54 \%$ during the one year of hydroxyurea therapy $(\mathrm{p}<0.0001)$. A total 38 out of 45 patients required hospitalization due to vaso-occlusive crisis before, but during one year of hydroxyurea therapy 15 out of 45 patients required hospitalizations. The mean frequency of hospitalizations due to vasoocclusive crisis was decreased by $78.43 \%$. The mean duration of hospital stay also decreased by $37.95 \%$ and it was statistically significant. Number of patients requiring blood transfusion decreased by $90 \%$ and mean frequency of blood transfusion decreased by $93.54 \%$. the decrease in clinical score was $29.50 \%$ in sickle cell patients (both SS and AS pattern) which was statistically significant (table.1)

In the present study it was found that the baseline mean fetal hemoglobin level was 15.52 with the range 0.4-34.1. Fetal hemoglobin level after one year of hydroxyurea therapy was 19.73 with the range 0.7-44.6. The mean hemoglobin level increased significantly by $20.04 \%$ after hydroxyurea. The range of baseline hemoglobin in sickle cell patients (both SS and AS) was 6$12.2(\mathrm{gm} / \mathrm{dl})$ and after one year of therapy was 7.3$15(\mathrm{gm} / \mathrm{dl})$. The MCV i.e. mean corpuscular volume of red cell increased by $16.92 \%$. The total leukocyte count decreased significantly by
$34.93 \%$ but the platelet count decreased by $5.55 \%$ and this was not significant.(table.2)

In homozygous sickle cell cases (SS), mean frequency of vaso-occlusive crisis, frequency of hospitalizations, blood transfusions and clinical score decreased significantly by $78.58 \%, 78.67 \%$, $90.90 \%$ and $29.00 \%$ respectively with one year of hydroxyurea therapy. Similarly, mean fetal hemoglobin, hemoglobin, mean corpuscular volume significantly increased by $27.16 \%$, $21.83 \%$ and $15.65 \%$ respectively with one year of hydroxyurea therapy. Total leukocyte count decreased significantly by $36.86 \%$. The platelet count also decreased by $6.61 \%$ but it was not significant. (table.3 and 4)

In heterozygous sickle cell cases (AS), mean frequency of vaso-occlusive crisis, frequency of hospitalizations and clinical score significantly decreased by $87.83 \%, 86.44 \%$ and $31.42 \%$ respectively with one year of hydroxyurea therapy. But the decrease in the requirement of blood transfusions was not found to be statistically significant. Similarly, mean fetal hemoglobin, hemoglobin, and mean corpuscular volume significantly increased by $24.42 \%, 13.47 \%$ and $22.35 \%$ respectively with one year of hydroxyurea therapy. Total leukocyte count decreased significantly by $35.35 \%$. The platelet count also decreased by $1.47 \%$ but it was not significant. (table.5 and 6)

When the clinical and hematological response to hydroxyurea therapy was compared between SS and AS cases, though there was decrease in frequency of vaso-occlusive crisis, frequency of hospitalizations, blood transfusions and clinical score in both, the difference between the two groups was not statistically significant. Fetal haemoglobin increased in both the groups and the mean change in $\mathrm{HbF}$ was significantly high in SS cases.(table.7)

Correlation of the change in clinical and hematological parameters after one year of hydroxyurea therapy with baseline fetal hemoglobin level demonstrated that change in 
mean corpuscular volume had a negative correlation and it was statistically significant.

There was positive correlation of change in vasoocclusive crisis, hemoglobin level and fetal hemoglobin with baseline fetal hemoglobin, but it was not statistically significant. There was negative correlation of change in hospitalizations, blood transfusion required, clinical score, platelet count and total leukocyte count with baseline fetal hemoglobin level, but this was also not statistically significant.(table.8)

In the present study, total 54 cases fulfilling eligibility criteria, were initially recruited in the study. 2 cases developed severe adverse drug reaction- One had severe bone marrow suppression and the other developed generalized vasculitic skin rash. 3 patients had nausea and skin pigmentation and they stopped hydroxyurea on their own. 4 cases were noncompliant. When all 54 cases were considered, hematological adverse drug reaction was noted in 11 out of 54 i.e. 20.37\%. These included thrombocytopenia, leucocytopenia, thrombocytopenia with leucocytopenia and pancytopenia. Following this was gastrointestinal side effects seen in 10 out of 54 cases $(18.51 \%)$. These included abdominal pain and nausea in two cases and nausea in eight cases. Dermatological side effects were seen in 8 cases (14.81\%). These included skin hyperpigmentation, nail pigmentation, hair loss and skin rash .Vertigo has been observed in 2 (3.7\%), edema feet in $1(1.8 \%)$ and weight loss in one case $(1.8 \%)$. (table.9)

\section{Discussion}

Sickle gene is an example of balanced polymorphism. It is nature's way of resisting malarial parasites. Mode of inheritance is autosomal recessive. Most of the patients with sickle cell disease suffer from intermittent episodes of vaso-occlusion due to sickled red blood cells in connective and musculoskeletal structures resulting in painful ischemia manifested as acute pain and tenderness, fever, tachycardia and anxiety. These recurrent episodes, called painful/vaso-occlusive crises have also been reported in sickle cell trait patients.

Fetal Hemoglobin ( $\mathrm{HbF}$ ) level has been a useful criterion in predicting the clinical severity of sickle cell disease. Higher $\mathrm{HbF}$ levels are associated with lesser clinical severity in sickle cell anemia patients . ${ }^{10}$

Hydroxyurea has been used in the treatment of leukemia. It was observed that hydroxyurea stimulated $\mathrm{HbF}$ production and this led to clinical studies of hydroxyurea in sickle cell disease. Hydroxyurea has become the primary drug for reducing vaso-occlusive crises and improving the quality of life of sickle cell disease and is also used for increasing fetal hemoglobin in $\mathrm{HbC} / \mathrm{S}$ patients. It is given in the dose of $10 \mathrm{mg} / \mathrm{kg}$ per day and titrated upwards in sickle cell disease. ${ }^{4}$

Hydroxyurea has various effects-the most important is increase in $\mathrm{HbF}$ level. It also increases the total haemoglobin and hematocrit. It increases the mean corpuscular volume of red blood cells and improves their hydration resulting in better lifespan of the cell. The decrease in haemoglobin polymerisation improves red cell rheology.It is also reported that there is a reduction in expression of adhesion molecules on the surface of red blood cell. High neutrophil counts are associated with worse clinical prognosis and early death. Neutrophils adhere to vascular endothelium, impending flow of the sickled red cell, increase blood viscosity and release inflammatory cytokines; activation and production of toxic oxygen radicals has also been reported. Hydroxyurea decreases the marrow production of neutrophils and exerts beneficial effect. It is also a nitric oxide (NO) donor. Nitric oxide maintains vascular tone and improves endothelial function. ${ }^{11,12,13}$

The present study of 45 cases (36 homozygous and 9 heterozygous) of sickle cell disease observed statistically significant improvement in clinical parameters namely, frequency of VOC's, frequency of hospitalization for VOC's, duration of hospital stay, requirement of blood transfusion and clinical score. Though published data on 
vasoocclusive crisis in sickle cell trait is limited, $20 \%$ of our cases with painful crisis were HPLC proven sickle cell trait.51.11\% of our cases did not have further crisis. Mean frequency of VOC's decreased by $81.54 \%$ during one year of hydroxyurea therapy.

Studies by Italia. K., Singh. H, and Jain.D. have observed similar response. , $^{9,15,16,17}$

In accordance with the Arabian-Indian haplotype, the baseline fetal haemoglobin was $15.52 \pm 9.14$. It increased significantly by $27.06 \%$ at the end of one year therapy. The total hemoglobin, mean corpuscular volume significantly increased in both homozygous (SS) and heterozygous (AS) cases and the total leukocyte count significantly decreased in both the groups. Thus statistically significant clinical and haematological response was obtained despite high level of $\mathrm{Hb} \mathrm{F}$. This highlights the pleiotropic and salutary effects of hydroxyurea.

Arabian study by Ali.Hal-Jama and Indian studies by Italia.K, Singh.H, and Jain.D. on homozygous cases have reported similar findings. ${ }^{7,9,14,15}$ Heterozygous sickle cell studies by Italia. K, Patel. S, Miller. M. Kand Yates .A.M have also reported clinical and haematological improvement similar to our observations. ${ }^{6,9,18,19}$

Hydroxyurea treatment was effective in homozygous as well as heterozygous sickle cell cases. Vaso-occlusive crisis has been consistently observed over many years in some cases of heterozygous sickle cell. No significant difference was observed in clinical and haematological response between the two groups except $\mathrm{HbF}$ response. $\mathrm{HbF}$ increased in both, but the rise in SS cases was significantly higher than AS cases. It may be inferred that the pleiotropic effects of hydroxyurea have contributed for improvement of VOC's in AS cases. Large sample size studies are required to evaluate the role of hydroxyurea in AS cases.

Clinical and haematological parameters were correlated with baseline $\mathrm{HbF}$ level. Only MCV negatively and statistically correlated with Baseline $\mathrm{HbF}$ level; a higher increase in MCV was noted with lower baseline $\mathrm{HbF}$ level ${ }^{4}$. It may be inferred that clinical and haematological response to hydroxyurea therapy may not correlate with baseline $\mathrm{HbF}$ levels. Hydroxyurea therapy is therefore recommended in cases of sickle cell disease and trait.

Hydroxyurea was tolerated well in the present study; but regular monitoring is essential and drug may be discontinued if warranted. ${ }^{20}$

\section{Limitations}

1) We could recruit only 9 sickle cell trait cases as against 36 of homozygous sickle cell cases.

2) The follow up duration of the study was one year. Longer duration of follow up is warranted in order to study long term effects of hydroxyurea in sickle cell cases.

3) Detailed structural studies of hemoglobin and genetic analysis is indicated in heterozygous cases (AS pattern) presenting with severe painful crisis.

\section{Conclusions}

1) Hydroxyurea is effective in the management of homozygous sickle cell cases (SS pattern;. Hydroxyurea therapy results in statistically significant clinical and hematological response.

2) Hydroxyurea is effective in the management of heterozygous sickle cell cases; (AS pattern- sickle cell trait). Hydroxyurea therapy results in statistically significant clinical and hematological response Studies recruiting large number of heterozygous (AS pattern) cases are recommended.

3) Despite high levels of fetal hemoglobin, hydroxyurea exerts its benefits through hemorheological mechanisms.

4) Major adverse drug reactions were noted in 2 cases in the form of severe marrow suppression and generalized vasculitic rash. The drug was well tolerated otherwise. We emphasize that the treatment with hydroxyurea requires regular monitoring and follow up. 
Conflict of Interest: The authors report no conflict of interest.

Acknowledgement: We sincerely acknowledge the guidance of Late. Dr. S.S. Agarwal (Assoc. Prof. of Medicine, IGGMC).

\section{References}

1. Wang WC: Sickle cell anemia and other sickling syndromes. In: Greer JP, Rodgers GM, Foerster J, Paraskevas F, Lukens JN, Glader B, editors. Wintrobe's Clinical Haematology. Philadelphia: Lippincott Williams and Wilkins A Wolters Kluver company; 2004:1263-1311

2. Kar BC.Sickle cell disease in India. J Assoc Physicians India 1991;39(12):954960

3. Powars DR, Chan L, Schroeder WA. The influence of fetal haemoglobin on the clinical expression of sickle cell anemia. Ann N Y Acad Sci.1989;565:262-278

4. Charache S, Terrin ML, Moore RD et al .Effect of hydroxyurea on the frequency of painful crisis in sickle cell anemia.I nvestigators of the multicentre study of hydrxyurea in sickle cell anemia. N Engl J Med 1995;332:1317-1322

5. Steinberg MH, Nagwl RL, Brugnara C. Cellular effects of hydroxyurea in $\mathrm{HbSC}$ disease. British Journal of Hematology; 1997:838-844

6. Patel S, Purohit P, Mashon RS et al. The effect of hydroxyurea on compound heterozygotes for sickle cell hemoglobin D Punjab-A single centre experience in eastern India. pediatric blood and cancer2014;61(8):1341-1346

7. Al-Jama AH, Al-Dabbous IA et al. Hydroxyurea in sickle cell disease patients from Eastern Saudi Arabia. Saudi Med J 2002;23(3):277-281

8. Surve RR, Mukherjee MB, Kate SL et al. Detection of beta $S$ gene: an evaluation of the solubility test against automated chromatography and hemoglobin electrophoresis. $\mathrm{Br} \quad \mathrm{J}$ Biomed Sci 2000;57:292-294

9. Italia $K$, Jain $D$, Gattani $S$ et al. Hydoxyurea in sickle cell disease-a study of clinico-pharmacological efficacy in the Indian haplotype. Blood Cell, Molecules and Disease 2008;42(1):25-31

10. Steinberg MH et al: Sickle cell disease and other hemoglobinopathies. In: Lee Goldman, Andrew Schafer, editors. Cecil Medicine. Philadelphia: Elsevier Saunders; 2012. Chapter 166;1066-1074

11. Charache S. Mechanism of action of hydroxyurea in the management of sickle cell anemia in adults. Semin Hematol 1997;34(Suppl.3):15-21

12. Ballas SK, Dover GJ, Charache S. Effect of hydroxyurea on the rheological properties of sickle erythrocytes in vivo. Am J Hematol 1989;32:104-111

13. Russell E. Ware, Banu Aygun. Advances in the use of Hydroxyurea. Hematology 2009;34:62-69

14. Patel DK, Mashon RS, Patel S et al.Low dose Hydroxyurea is effective in reducing the incidence of painful crisis and frequency of blood transfusion insickle cell anemia patients from eastern India. Hemoglobin; 2012.vol.36:409-420

15. Singh H, Dulhani N, Kumar BN et al. Effective control of sickle cell disease with hydroxyureatherapy. Indian J Pharmacology 2010;42(1):32-35

16. Colah RB, Mukherjee M, Ghosh K. Sickle cell disease in India. Curropin Hematol 2014;21(3):215-223

17. Colah RB, Mukherjee M, Ghosh K, Snehal M. Sickle cell disease in tribal populations in India. Indian $\mathrm{J}$ Med Res 2015;141(5):509-515

18. Yates AM, Dedeken L, Smeltzer MP et al. Hydroxyurea treatment of children with Hemoglobin SC disease. Pediatric Blood Cancer 2013;60(2):323-325 
19. Miller MK, Zimmerman SA, Schultz WH, Ware RE et al. Hydroxyurea therapy for pediatric patients with haemoglobin SC disease. J Pediatric Hemat Oncol 2001;23(5):306-313

20. Ballas SK, Singh P Adams-Graves P et al. Idiosyncratic side effects of Hydoxyurea in patients with sickle cell anemia. J Blood Disorders and Transfusion 2013;4:162165. 